\title{
Sedimentary Environment and Sequence Stratigraphy of the Asmari Formation at Khaviz Anticline, Zagros Mountains, Southwest Iran
}

\author{
Abdolhosein Kangazian*, Mohammad Pasandideh \\ Department of Geology, Faculty of Sciences, Islamic Azad University, Isfahan (Khorasgan) Branch, Isfahan, Iran \\ Email: "kangazian@khuisf.ac.ir
}

Received 30 November 2015; accepted 12 February 2016; published 16 February 2016

Copyright (C) 2016 by authors and Scientific Research Publishing Inc.

This work is licensed under the Creative Commons Attribution International License (CC BY).

http://creativecommons.org/licenses/by/4.0/

(c) (i) Open Access

\begin{abstract}
The Oligocene-Miocene Asmari Formation is a thick sequence of shallow water carbonates of the Zagros Basin. Khaviz Anticline outcrop [near Behbahan city/Iran] was studied in this research in order to interpret the facies, depositional environment and sequence stratigraphy of the Asmari Formation succession. In this study, twelve different microfacies types have been recognized, which can be grouped into five (micro) facies associations: peritidal, lagoon, shoal, semi restricted marine and open marine. The Asmari Formation represents sedimentation on a carbonate ramp. According to the fauna data, the Asmari Formation is Oligocene (Rupelian/Chattian) to Early Miocene (Burdigalian) in age at the study area. Eight third-order depositional sequences are identified on the basis of deepening and shallowing patterns in the microfacies. The depositional sequences 0 and 1 (Rupelian-Chattian), 2, 3 and 4 (Chattian) were referred to the lower while sequences 5 and 6 (Aquitanian) were referred to the middle and sequence 7 (Burdigalian) was referred to the upper Asmari Formation. The relative sea-level curve of the Asmari basin and its matching with the global sea-level curves documented that Global eustatic phenomena affected this basin.
\end{abstract}

\section{Keywords}

Asmari Formation, Zagros Basin, Sequence Stratigraphy, Sedimentary Environment, Oligocene-Miocene

\section{Introduction}

Carbonate platform deposits that form the Asmari Formation contain some of the largest oil reservoirs in the ${ }^{*}$ Corresponding author.

How to cite this paper: Kangazian, A. and Pasandideh, M. (2016) Sedimentary Environment and Sequence Stratigraphy of the Asmari Formation at Khaviz Anticline, Zagros Mountains, Southwest Iran. Open Journal of Geology, 6, 87-102. 
world [1]. This formation crops out in a $1200 \mathrm{~km}$ long by $200 \mathrm{~km}$ wide belt extending from northeast Iraq to southwest Iran [2]. An Oligocene (Rupelian) to Early Miocene (Burdigalian) age has been determined for the formation based mainly on foraminiferal zones and strontium isotope stratigraphy [3] [4]. The Asmari deposition took place on a carbonate platform at the margin of a NW-trending foreland basin in the Zagros orogenic belt [5] [6]. More recent studies of the Asmari Formation have been conducted on biostratigraphic criteria (e.g. [7]-[9]), microfacies and depositional environments (e.g. [7] [10] [11]), depositional environment and sequence stratigraphy (e.g. [3]-[5]).

This paper, which deals with sedimentology and sequence stratigraphy of the Asmari Fm. in the Khaviz outcrop, has three objectives: 1) the description of the facies and their distribution on the Oligocene-Miocene carbonate platform, 2) the reconstruction of the carbonate paleoenvironment, and 3) the distinguishing of the $3^{\text {rd }}$ order sequences that developed in the study area.

\section{Methods and Study Area}

The Asmari Formation succession (294 m thick) was measured bed by bed, and sampled in the Khaviz anticline (in the Tang-e-Khaiez valley) north of Behbahan City (Khuzestan Province, Figure 1), and sedimentologically examined. Based on the Stow [12], the section was described in the field, including their weathering profiles, facies and bedding surfaces. Facies characteristics were described in thin sections from 211 samples, according to the schemes proposed by Wright [13], and contrasted with the microfacies proposed by Flügel [14]. Walter's law and facies relationships were calculated based on the proposed methods by Selly [15]. Methods and terminology which were planned by Catuneanu et al. [16] and Martin-Chivelet [17] were used for description and analyze of the sequence stratigraphy. The latter method was used with some modification, in this paper. Biozonation and age determinations are based on strontium isotope stratigraphy recently established for the Asmari Formation by Van Buchem et al. [4] (Figure 2).

\section{Results}

\subsection{Geological Setting}

The Iranian Plateau has been subdivided into eight continental fragments, including Zagros, Sanandaj-Syrjan, Urumieh-Dokhtar, Central Iran, Alborz, Kopeh-Dagh, Lut, and Makran. The Zagros region is an active growth

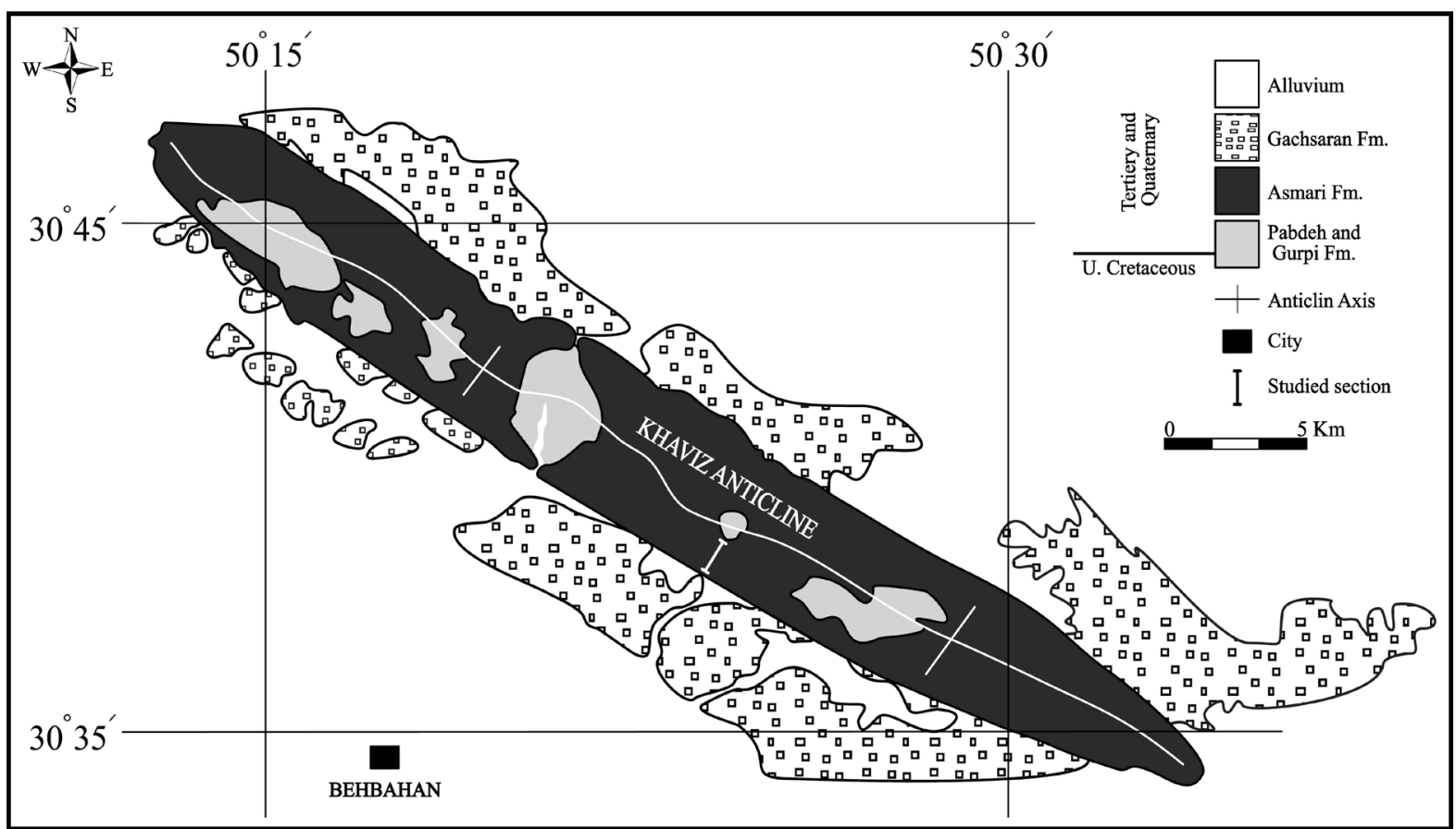

Figure 1. Location and geological map of the study area, Khaviz Anticline, southwest Iran. 


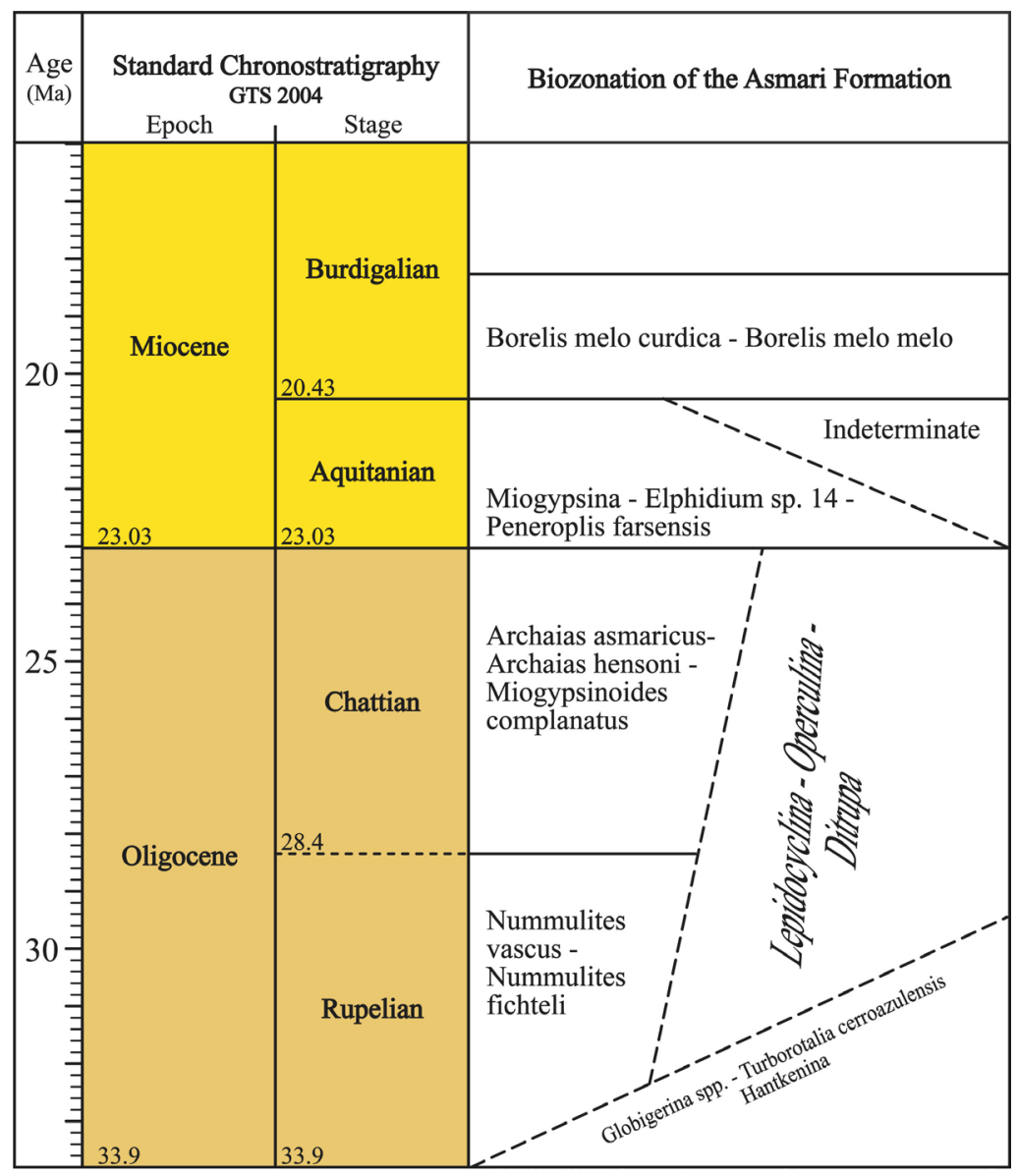

Figure 2. Biozonation of the Asmari formation, after van Buchem et al. [4].

area of the mountains belt expanded between convergence plates of Arabia and Eurasia, and is located along the northeastern margin of Arabian plate [2]. This basin was part of the stable Gowndwana supercontinent in the Paleozoic, a passive margin in the Mesozoic, and became a site of convergent orogeny in the Cenozoic. During the Oligocene-Miocene this basin was gradually narrowed and the Asmari Formation was deposited [5].The Zagros orogenic belt of Iran, as part of the Alpine-Himalayan mountain chain, extends for about $2000 \mathrm{~km}$ in a NW-SE direction from the East Anatolian Fault of eastern Turkey to the Oman Line in southern Iran. This orogenic belt consists of three parallel belts: 1) The Zagros fold-thrust belt, 2) the imbricated zone, and 3) the Urumieh-Dokhtar magmatic assemblage [1]. On the basis of lateral facies variations, the Iranian Zagros fold-thrust belt is divided into different tectonostratigraphic domains that are from SE to NW: the Fars Province or eastern Zagros, the Izeh Zone and Dezful Embayment or Central Zagros and finally the Lurestan Province or Western Zagros. The study area, Khaviz anticline, is located in the Zagros fold-thrust belt and Dezful Embayment province. In this area (central Zagros), the lower part of the Asmari Formation interfingers with the Pabdeh Formation and its upper part is covered by the Gachsaran Formation (Figure 1).

\subsection{Biostratigraphy (Figure 3 \& Figure 4)}

Four assemblages of foraminifera recognized in the studied area and were discussed in ascending stratigraphic order as follows:

Assemblage 1

The most important foraminifera in this assemblage are: Eulepidina elephantina, Eulepidina dilatata, Nephrolepidina tournoueri, Heterostegina sp., Operculina sp., Spiroclypeus sp., Amphistegina sp. and miliolids. This assemblage is correlated with Lepidocyclina-Operculina-Ditrupa Assemblage zone of Van Buchem et al. [4] and is attributed to the Rupelian-Chattian age (Figure 4). 
Assemblage 2

The most diagnostic species in this assemblage include: Archaias kirkukensis, Archaias sp., Archaias operculiniformis, Archaias asmaricus, Peneroplis thomasi, Meandropsina iranica, Spiroclypeus blanckenhorni, Elphidium sp. Dendritina rangi, and miliolids. The assemblage corresponds to Archaias asmaricus-Archaias hensoni-Miogypsinoides complanatus assemblage zone of Van Buchem et al. [4] of Chattian age (Figure 6). Amirshahcarmi et al. [10] also recognized Archaias operculiniformis in this assemblage and referred it to Chattian age.

Assemblage 3

Foraminifera of assemblage 3 include Miogypsina sp., Elphidium sp., Peneroplis sp., Triloculina trigonula, Amphistegina sp., Miogypsinoides sp., Dendritina rangi, Discorbis sp., and miliolids. This assemblage is correlated with Miogypsina-Elphidium sp. 14-Peneroplis farsensis Assemblage zone of Van Buchem et al. [4] and is attributed to the Aquitanian (Figure 4).

Assemblage 4

Assemblage 4 is characterized by the presence of Borelis melo curdica, Dendritina rangi, Borelis sp., small rotaliids, Discorbis sp., miliolids and echinoid debris. These microfauna correspond to the Borelis melo curdica-B. melo melo Assemblage zone of Van Buchem et al. [4] and indicate a Burdigalian age (Figure 4).

\subsection{Microfacies Analysis}

Field and microscopic analysis of the Asmari Formation in the study area resulted in the definition of 12 microfacies types. Each of the microfacies exhibits typical textures and skeletal and non-skeletal components. The general description and interpretation of the microfacies are discussed from deep to shallow in the following paragraphs.

\subsubsection{Microfacies 1) Corallinacean, Larger Foraminofera, Wackestone-Packstone}

The main components are reworked corallinacean fragments and large perforate foraminifera (Figure 5(a)). The foraminifera are characterized by a relatively diverse assemblage of nummulitids (Operculina, Heterostegina
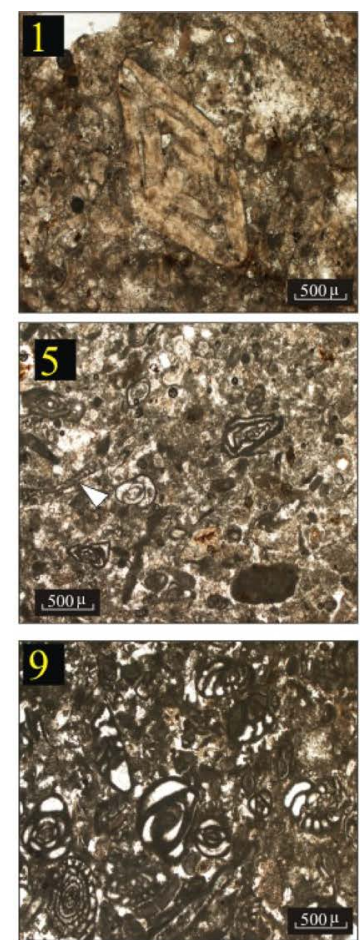
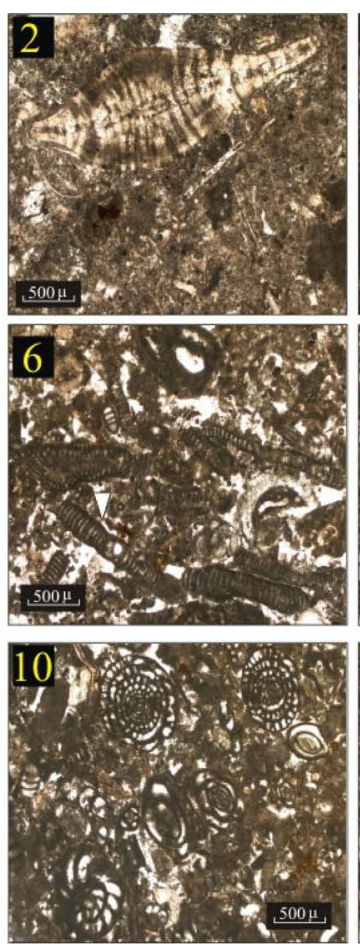
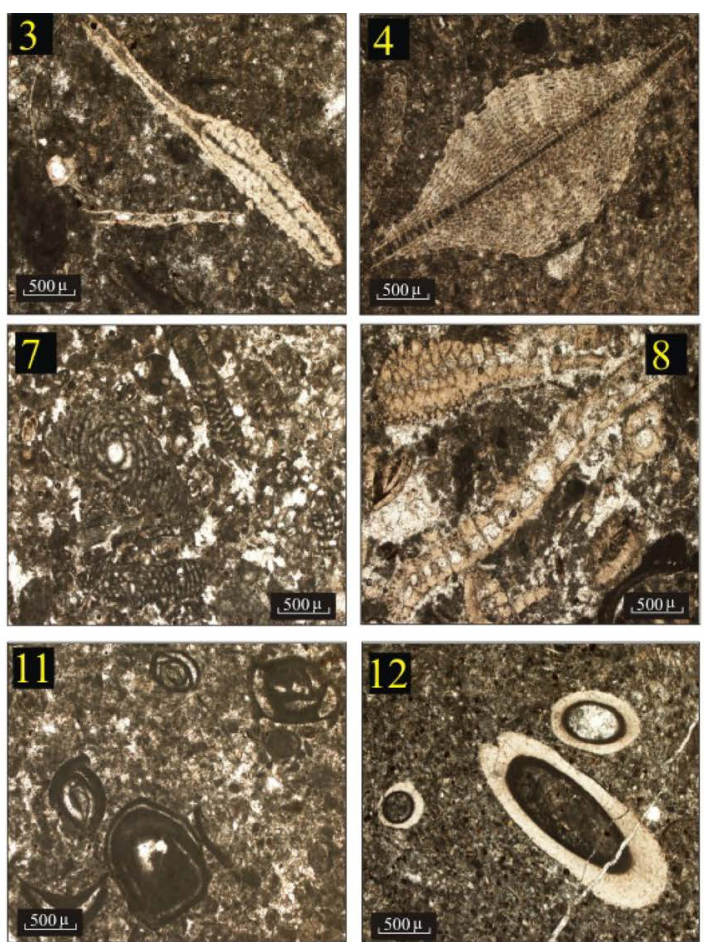

Figure 3. Indexing foraminifera: (1) Nummulites sp., (2) Hetrostegina sp., (3) Operculina sp., (4) Lepidocyclina sp., (4) Meandropsina sp., (5) Penerplis sp. (white arrow), (6) Archaias sp. (white arrow), (7) Myogipsina sp., (8) Dentrina rengi, (9) Borelis melo curdica, (10) Miliolida sp., (11) Ditrupa sp., (12) Ditrupa sp. 
A. Kangazian, M. Pasandideh

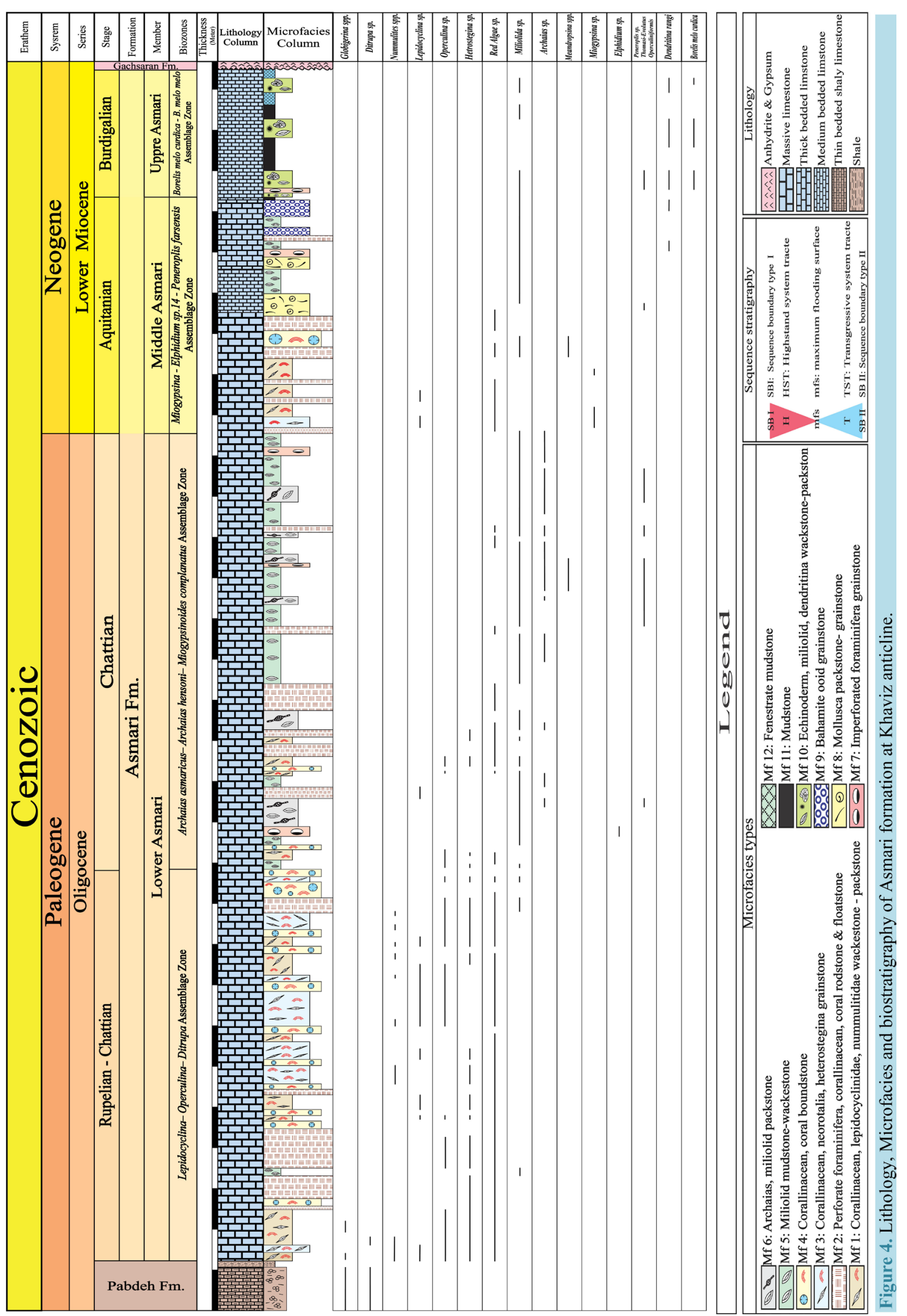


and Spiroclypeus) and lepidocyclinids (Eulepidina and Nephrolepidina). The minor components are echinoderm and bryozoan fragments (Figure 5(b)).

Interpretation: The combination of micritic matrix and abundance of typical open-marine skeletal fauna including bryozoans, echinoids, and larger foraminifera suggest a low-medium energy, open-marine environment for deposition of this microfacies [14]. The presence of large and flat nummulitids and lepidocyclinids allowed us to interpret this facies as having been deposited in the lower photic zone [5] [18]-[21] on the distal openmarin. This microfacies is as the same as RMF13 [14].

\subsubsection{Microfacies 2) Benthic Foraminifera Corallinacean Coral Floatstone-Rudstone}

The main characteristic of this microfacies is abundant large fragments of corallinacean, corals and benthic foraminifers (lepidocyclina, Operculina, and Heterostegina). Echinoid and bryozoan fragments are also present. The fragments are coarse sand to granule in size (Figure 5(c) and Figure 5(d)).

Interpretation: most of the main components of this facies are reef drived fragments (i.e. corallinacean and coral fragments).So they came from an open marine environment under normal marine salinity conditions with open water circulation and medium hydrodynamic energy. Evidence for this interpretation includes abundant open marine skeletal fauna [10] and stratigraphic position. Abundant open marine skeletal fauna and flora reflect well-lit water and oxygen contents within the water column and at the sediment surface. Flügel [14] believes that boundstones are disintegrated by biological and physical erosions and their fragments are reworked and, finally, these fragments produced such facies. Microfacies 2 is comparable with RMF15 [14].

\subsubsection{Microfacies 3) Corallinacean Neorotalia heterostegina Grainstone}

Identifiable components of this facies include benthic foraminifera (mainly Neorotalia, Heterostegina and rarely Operculina, Miogypsina, Amphistegina and lepidocyclina) and corallinacean fragments. Echinoderm segments are less common. Grains are fine- to coarse-sand size and sorting is moderate (Figure 5(e) and Figure 5(f)).

Interpretation: The presence of high diverse stenohaline fauna such as red algae, echinoid and larger foraminifera [like Neorotalia, and Heterostegina] indicate that the sedimentary environment was situated in the oligophotic zone in a shallow open marine environment [22]-[25]. The texture of this facies indicate moderate to high energy shallow waters with much movement. Pomar [21] believes that presence of Neorotalia and Heterostegina points to high energy shallow marine water in reef and intra-reef districts. This microfacies is equivalence of RMF13 [14].

\subsubsection{Microfacies 4) Corallinacean Coral Boundstone}

The main characteristic of this microfacies is abundant colony of corallinacean and corals. Coral skeletal form the framework of the facies and red algae have encrusting rules (Figure 6). In field, this microfacies is patch form and doesn't continue laterally. This facies mostly intercalates with the other open marine microfacies (Figure 5(g) and Figure 5(h)).

Interpretation: Corallinacean and coral reefs are interpreted as open marine facies of an inner ramp with free marine water-circulation, above the fire-weather wave base [14]. This interpretation is supported by patchy form of the facies. The microfacies is comparable with RMF12 [14].

\subsubsection{Microfacies 5) Miliolids Mudstone-Wackestone (Figure 5(i))}

Identifiable components of this facies include benthic imperforate foraminifera (especially miliolids). Archaias, echinoid, large foraminifers and corallinacean (broken fragments) are less common. Texture varies from mudstone to wackestone.

Interpretation: This facies was deposited in a semi restricted, low-energy condition. This condition is suggested by the rare normal marine biota, abundant skeletal components of restricted biota (imperforate foraminifera such as miliolids) and mud-supported fabric [14]. This microfacies is as the same as RMF16 [14].

\subsubsection{Microfacies 6) Archaias Miliolids Packstone}

Skeletal grains consist of diverse imperforate foraminifera (miliolids, Archaias, Peneroplis, and Meandropsina). Additional minor components are echinoderm fragments, corallinacean fragments, perforate foraminifera, and peloids. Lime mud occupies the pores of this grain-supported texture (Figure 5(j)).

Interpretation: Co-occurrence of normal marine (perforate foraminifera and corallinacean) and platform-interior 
(imperforate foraminifera) components indicates that sedimentation took place in a semi restricted, low-energy environment. Both porcellaneous and hyaline foraminifer indicate that the sedimentary environment was situated in the euphotic zone [25]. Seyrafian et al. [11] reported miliolids, Archaias and Peneroplis from restricted facies of the Asmari formation in central and north-central of Zagros basin. RMF 16 [14] is proposed for equivalent of the microfacies.

\subsubsection{Microfacies 7) Imperforate Foraminifera Grainstone}

The main well-sorted components are porcellaneous imperforate foraminifera like miliolids, Archaias, Mean-

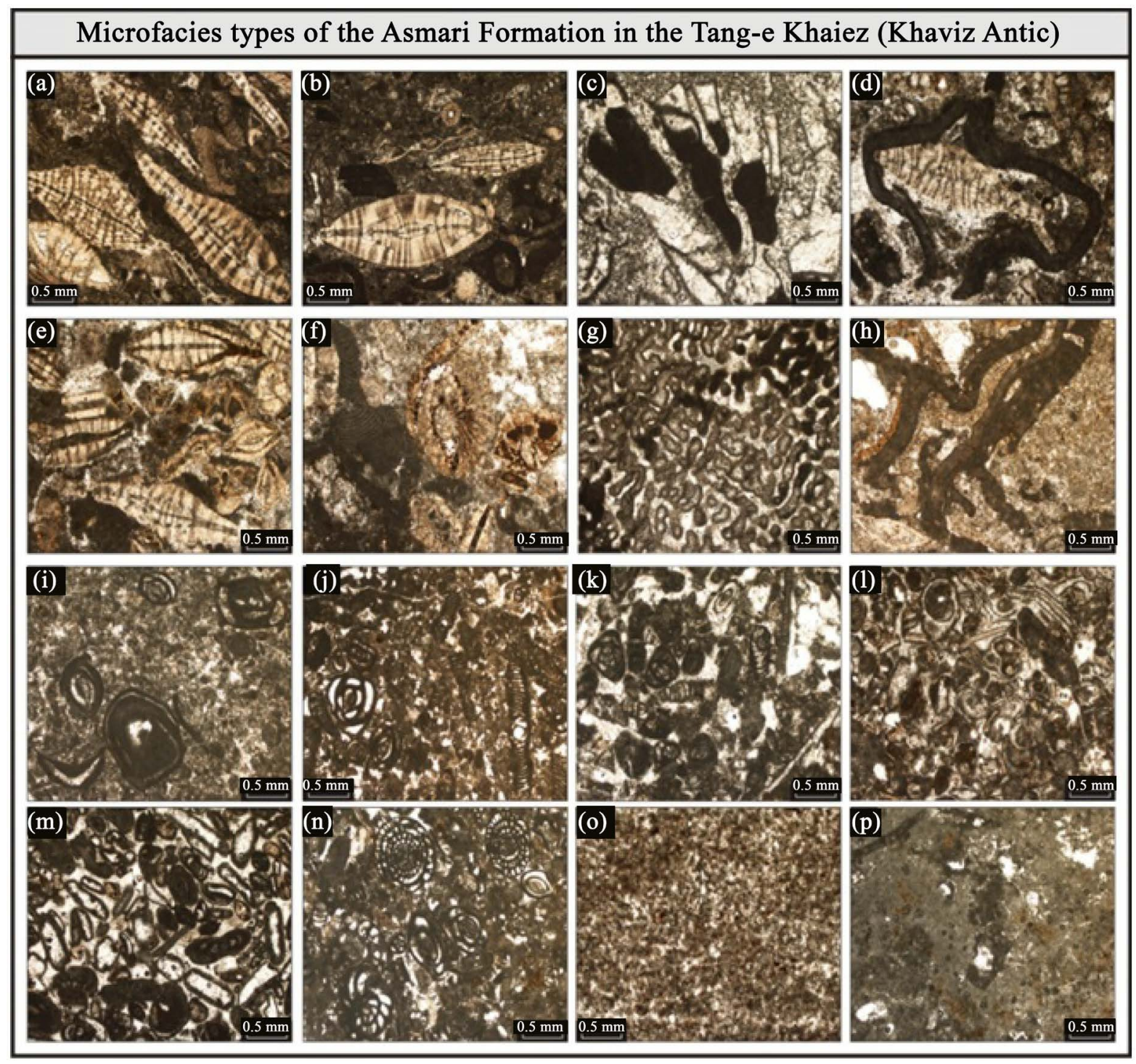

Figure 5. Microfacies types of the Asmari Formation in the Tang-e Khaiez (Khaviz Anticline, Khuzestan provinence, Iran): (a) Mf 1: Corallinacean lepidocyclinidae nummulitidae wackestone-packstone (Sample No. 63). (b) Mf 1: Corallinacean lepidocyclinidae nummulitidae wackestone-packstone (Sample No. 64). (c) Mf 2: Benthic foraminifera corallinacean coral floatstone-rudstone (Sample No. 32). (d) Mf 2: Benthic foraminifera corallinacean coral floatstone-rudstone (Sample No. 36). (e) Mf 3:Corallinacean Neorotalia Heterostegina grainstone (Sample No. 53). (f) Mf 3: Corallinacean Neorotalia Heterostegina grainstone (Sample No. 53). (g) Mf 4:Corallinacean coral boundstone (Sample No. 40). (h) Mf 4: Corallinacean coral boundstone (Sample No. 65). (i) Miliolids mudstone-wackestone (Sample No. 123). (j) Archaias miliolids packstone (Sample No. 139). (k) Imperforate foraminifer grainstone (Sample No. 146). (l) Mollusca packstone-grainstone (Sample No. 172). (m) Bahamite ooid grainstone (Sample No. 190). (n) Echinoderm miliolids Dendritina wackestone-packstone (Sample No. 197). (o) Mudstone (Sample No. 202). (p) Fenestrate mudstone (Sample No. 210). 


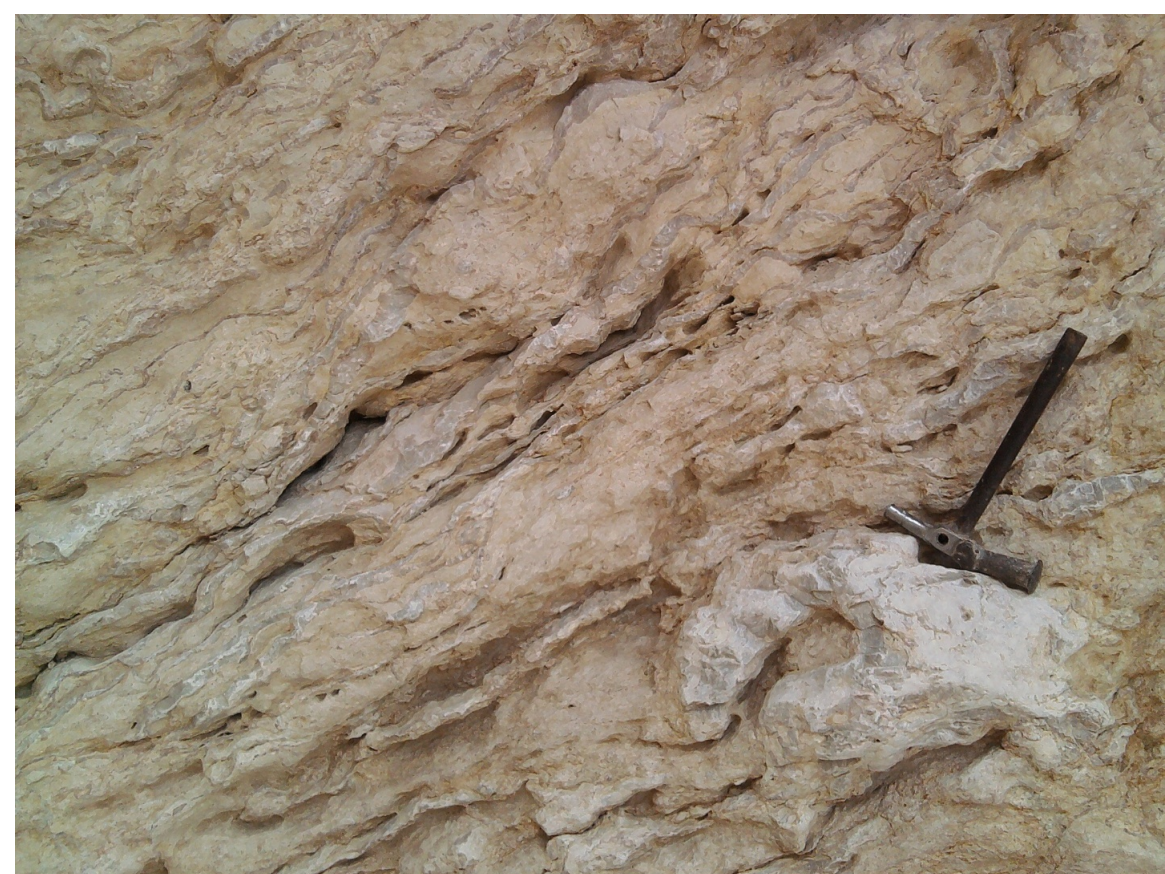

Figure 6. Corallinacean coral boundstone facies in the field.

dropsina and Dendritina. Echinoderm, mollusk fragments and peloid are also present (Figure 5(k)).

Interpretation: The features of this facies indicate high energy shallow waters with much movement and reworking of bioclasts. Sediments are interpreted to have been deposited in sand shoal [14] or next to it. The presence of diverse porcellaneous imperforate foraminifera and grainstone texture indicate that the facies occurred in the photic zone near a high-energy environment-like a shoal. This microfacies is comparable with RMF27 [14].

\subsubsection{Microfacies 8) Mollusca Packstone-Grainstone}

The main characteristic of this microfacies is abundant fragments of bivalve and gastropods. The minor components are peloid and porcellaneous imperforate foraminifera. Textures are dominantly grainstone, but range from packstone to grainstone (Figure 5(l)).

Interpretation: This facies which is equal of RMF26 [14], was deposited in a shoal. The shoal condition is suggested by the rare to absent lime mud and abundant sand-size shell fragments. Bivalves and gastropods, generally, live in shallow normal marine water. So, bioclastic shoals commonly separate restricted lagoonal environments from deeper ramp environments [14].

\subsubsection{Microfacies 9) Bahamite-Ooid Grainstone}

The predominant grain types are superficial and bahamite ooids. Skeletal grains such as mollusca and porcellaneous foraminifera and non-skeletal grain like aggregate grains, rarely, can be seen. Ooid nuclei consist of recrystallized bivalve and gastropod fragments, and miliolids with oval, circular or elongate outlines. Grains are fine- to coarse-sand size and sorting and roundness are moderates. Due to microbial micritization, some of ooids and bioclasts have been changed to bahamits and cortoids, respectively (Figure 5(m)).

Interpretation: The features of this facies indicate moderate to high energy shallow waters with much movement and reworking of bioclasts and the production of ooids. Sediments are interpreted to have been deposited in sand shoal [14]. A low sedimentation rate is suggested by micritization. The microfacies is as the same as RMF30 [14].

\subsubsection{Microfacies 10) Echinoderm Miliolids Dendritina Wackestone- Packstone}

A diverse assemblage of poorly to moderately sorted, fragmented and whole fossils in lime mud is characteristic of this microfacies. Echinoderm fragments, miliolids, and Dendritina are the dominant grains. Less common 
grains include Borelis, Quartz grain and fragments of recrystallized mollusca (Figure 5(n)). Textures range from wackestone to packstone. In a few samples; evaporate mineral moldings can be seen.

Interpretation: The occurrence of large number of porcellaneous imperforate foraminiferal tests may point to the depositional environment being slightly hypersaline. Such an assemblage is described as being associated with a shelf lagoon environment [26]. Microfacies10 is comparable with RMF20 [14].

\subsubsection{Microfacies 11) Mudstone}

This microfacies is composed of dense lime mudstones. Sediments also contain sparse ostracods, subordinate amounts of detrital quartz grains and gypsum. In some samples, gromlus fabric is produced by partially recrystalization of lime mud (Figure 5(0)). Microfacies11 occurs in upper part of the Asmari Formation, only.

Interpretation: Vaziri-Moghaddam et al. [5] believed that lime mudstone, with gypsum blades and small quartz grains and no evidence of subaerial exposure, was deposited in a restricted lagoon. This facies indicates hyper saline conditions within a lagoon. They reported such microfacies from northwestern of Zagros basin. This microfacies is similar to RMF19 [14].

\subsubsection{Microfacies 12) Fenestrate Mudstone}

This microfacies consists of fine grained microcrystalline limestone. Fenestrate structures are well developed, and algal filaments are rare (Figure 5(p)).

Interpretation: Birdseye or fenestral structures are typical products of shrinkage and expansion, gas bubble formation, and air escape during flooding, or may even result from burrowing activity of worms or insects [26]. These vuggies structures are typical of a tidal flat zone [5] [26]. Microfacies 11 occurs in upper part of the Asmari Formation and is the same as RMF23 [14].

\section{Discussion}

\subsection{Facies Associations}

According to their environmental interpretation and to their vertical transitions, recognized microfacies were subdivided into 5 basic types of facies associations: FA1) shallow marine environment, above fair-weather wave base, open water circulation with transitional to shallow normal-wave, FA2) above fair-weather wave base and semi-restricted water circulation, FA3) Shallow subtidal environment above fair-weather wave base and high energy, with shallow normal wave, FA4) above fair-weather wave base, hyper salinity and relatively calm water, and FA5) peritidal environment.

Shallow marine environment above fair weather wave base (with transitional to shallow normal-wave) can be compared to open marine portion of inner ramp with normal salinity and coral patch-reef/biostrome development. Subsequently, this facies association (FA1) is characterized by features pointing to low and moderate (sometimes high-energy) background conditions (matrix to grain-supported fabrics) and by presence of poorly or moderately diverse oligotrophic (rarely mesotrophic) patch-reef macro benthic assemblages like large foraminifera and echinoderms, and, also, coral, bryozoan and corallinacean sand-size and gravel-sized fragments. Typically, this facies association includes Corallinacean lepidocyclinid nummulitids wackestone-packstone (MF1), benthic foraminifera corallinacean coral floatstone- rudstone (MF2), Corallinacean Neorotalia Heterostegina grainstone (MF3) and Corallinacean coral boundstone (MF4).

Shallow marine environment above fair-weather wave base and semi-restricted water circulation, may be considered as semi-restricted marine portion of inner ramp with hyper salinity. This facies association (FA2) is typified by mud to grain-supported texture and by occurrence of imperforate foraminifera. Presence of some constituents of previous facies association reveals connection between open marine and semi-restricted marine. 2 microfacies types involve miliolids mudstone-wackestone (MF5) and Archaias miliolids packstone (MF6).

The shallow subtidal environment above fair-weather wave base and high energy, shallow normal wave is the same as shoal portion of inner ramp. This facies association (FA3) showing signs of long-term water agitation (packing, sorting, poor taphonomic preservation, ooids) were deposited in subtidal skeletal and oolithic banks, incipient shoals and bars and adjacent back-barrier depressions. 3 microfacies types involve Imperforate foraminifer grainstone (MF7), Mollusca packstone- grainstone (MF8) and Bahamite ooid grainstone (MF9).

The shallow subtidal environment above fair-weather wave base, hyper saline and relatively calm water can be compared to restricted lagoons of inner ramp. This facies association (FA4) is characterized by mud-supported 
texture, micritization, rare or absent of normal marine biota, abundant skeletal components of restricted biota, non-diversity, and lack of subaerial exposure. Typically, this facies association includes Echinoderm miliolids Dendritina wackestone-packstone (MF10), and Mudstone (MF11).

The peritidal environment, here, only is characterized by the presence of fenestrate fabric and is the same as peritidal of back-ramp (Figure 6). This facies association (FA5), merely, consists of fenestrate mudstone (MF12).

\subsection{Sedimentary Model}

Microfacies and facies associations analyses have permitted the differentiation of several carbonate marine system environments including open marine, semi restricted marine, shoal, lagoon and tidal flat (Figure 7). These 5 depositional environments of the Oligocene-Miocene in the study area are similar to those found in many modern carbonate depositional settings.

By comparing the microfacies criteria with those of modern carbonate depositional settings, such as the Persian Gulf, and prominent carbonate classical facies models, like Flügel's [14] model, a very low gradient homoclinal carbonate ramp model is suggested for the Asmari Formation in the Khaviz anticline (Figure 9). Lack of barrier reef supports this suggestion. It seems that the Asmari Formation depositional environment was similar to the modern homoclinal carbonate ramp of the Persian Gulf. Microfacies relationships [based on the results of the selly's method, 15], their situations in the succession, and, also, locations of their comparable RMFs in the Flügel's [14] facies model show that all the microfacies have deposited in inner portion of the ramp (Figure 7).

\subsection{Sequence Stratigraphy}

The studied succession can be framed in a sequence stratigraphic context. As a guide, we used the principal sequence stratigraphic concepts developed by many workers (e.g. [16] [17]) to recognize TST (transgressive systems tract), mfs (maximum flooding surface), HST (highstand systems tract) and sequence boundaries.

Based on the detailed sedimentology and stratigraphy study, on the parasequences and parasequence sets trends, on the vertically changes of the facies (Martin-Chivelet's method) [17] and environments (Shallowing diagram) along the succession, we defined one incomplete and seven complete third-order depositional sequences (Figure 8) as follow.

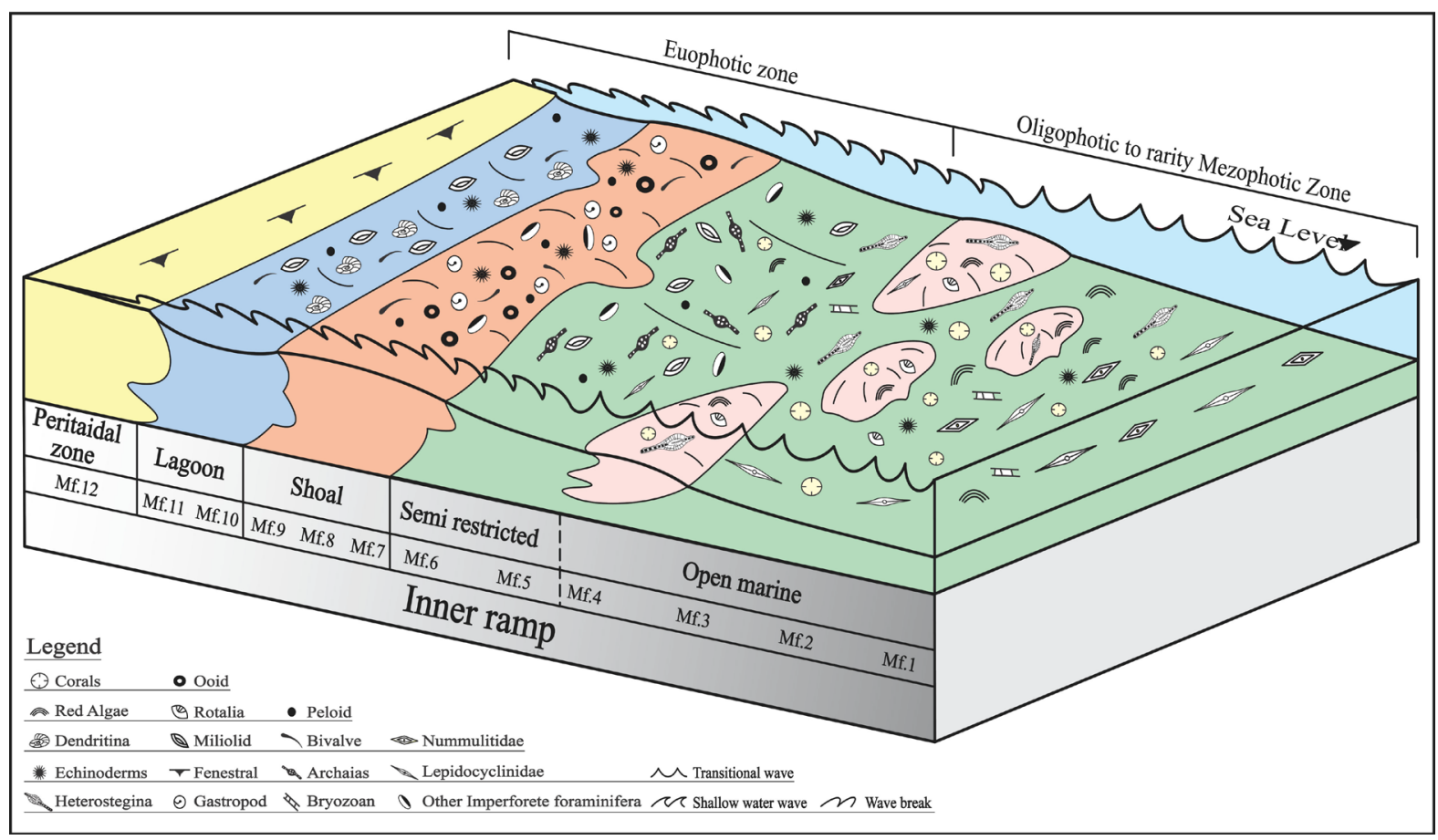

Figure 7. Depositional model for the platform carbonates of the Asmari formation at Tang-e Khaiez (Khaviz Anticline), Zagros Basin, SW Iran. The interpretation is adopted from Flügel [14]. 
A. Kangazian, M. Pasandideh

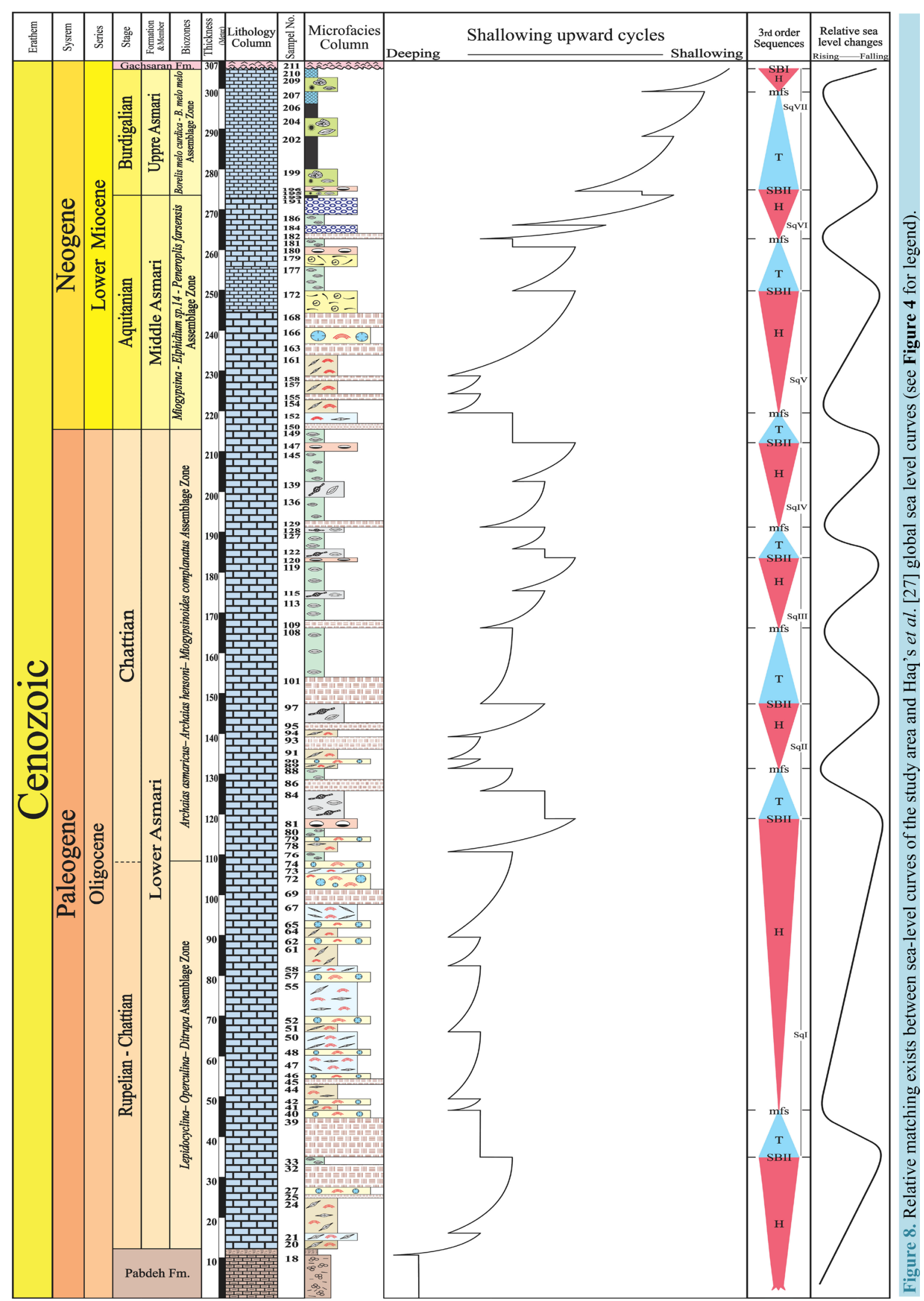




\subsubsection{Depositional Sequence 0}

Depositional sequence 0 encompasses the upper part of the Pabdeh Formation and the lower part of the Asmari Formation. Uppermost portion of its highstand systems tract (HST) is about $20 \mathrm{~m}$ thick and comprises the lower part of the Asmari Formation. The sediments of this part of sequence are Rupelian-Chattian in age. This interval consists of a prograding parasequences set that composes of open marine microfacies (Facies association 1). The contact between DS0 and DS1 is of the $\mathrm{SB}_{\text {II }}$ type (Figure 8). This sequence formed during the Rupelian-Chattian global transgression ( $3^{\text {rd }}$ order cycle no 4.4 of Hag et al. [27], Figure 9).

\subsubsection{Depositional Sequence 1}

The depositional sequence 1 formed during the Rupelian-Chattian regression ( $3^{\text {rd }}$ order cycle no. 4.5 of Hag et al. [27], Figure 10). The boundary between this sequence and previous sequence (Sb I) is comparable with sequence surface Ru30/Ch10 proposed by Ehrenberg et al. [3] and surface II reported by Van Buchem et al. [4] (Figure 10). The transgressive systems tract (TST) of DS1 is marked by deposition of Mf1, Mf2 and Mf4. These open marine microfacies (FA1) have deposited on top of the semi restricted marine microfacies (Mf5; FA2) of previous depositional sequence. Topmost microfacies of the TST (Mf1) represent the Mfs (Figure 8). This TST is $11.5 \mathrm{~m}$ thick and consists of one abnormal parasequence.

The HST of DS1 in the Khaviz section is $72.3 \mathrm{~m}$ thick and composes of early HST and late HST. Early HST is characterized by one aggrading parasequence set that composes of 4 parasequences. Late HST is illustrated by a prograding parasequence set which consists of 2 parasequences (Figure 8). Early HST consists of alternation of Mf1, Mf2 and Mf4 (open marine microfacies; FA1) but late HST is characterized by a progradation from open marine (Mf1, Mf2, Mf3 and Mf4; FA1) to semi restricted marine (Mf5; FA2) and finally to shoal facies (Mf7, FA3).

\subsubsection{Depositional Sequence 2}

The depositional sequence 2 formed during commence of the early Chattian regression $\left(3^{\text {rd }}\right.$ order cycle no. 1.1 of Hag et al. [27]; Figure 9). In this area, this sequence is $28.5 \mathrm{~m}$ thick (Figure 8) and begins with $12 \mathrm{~m}$-thick se-

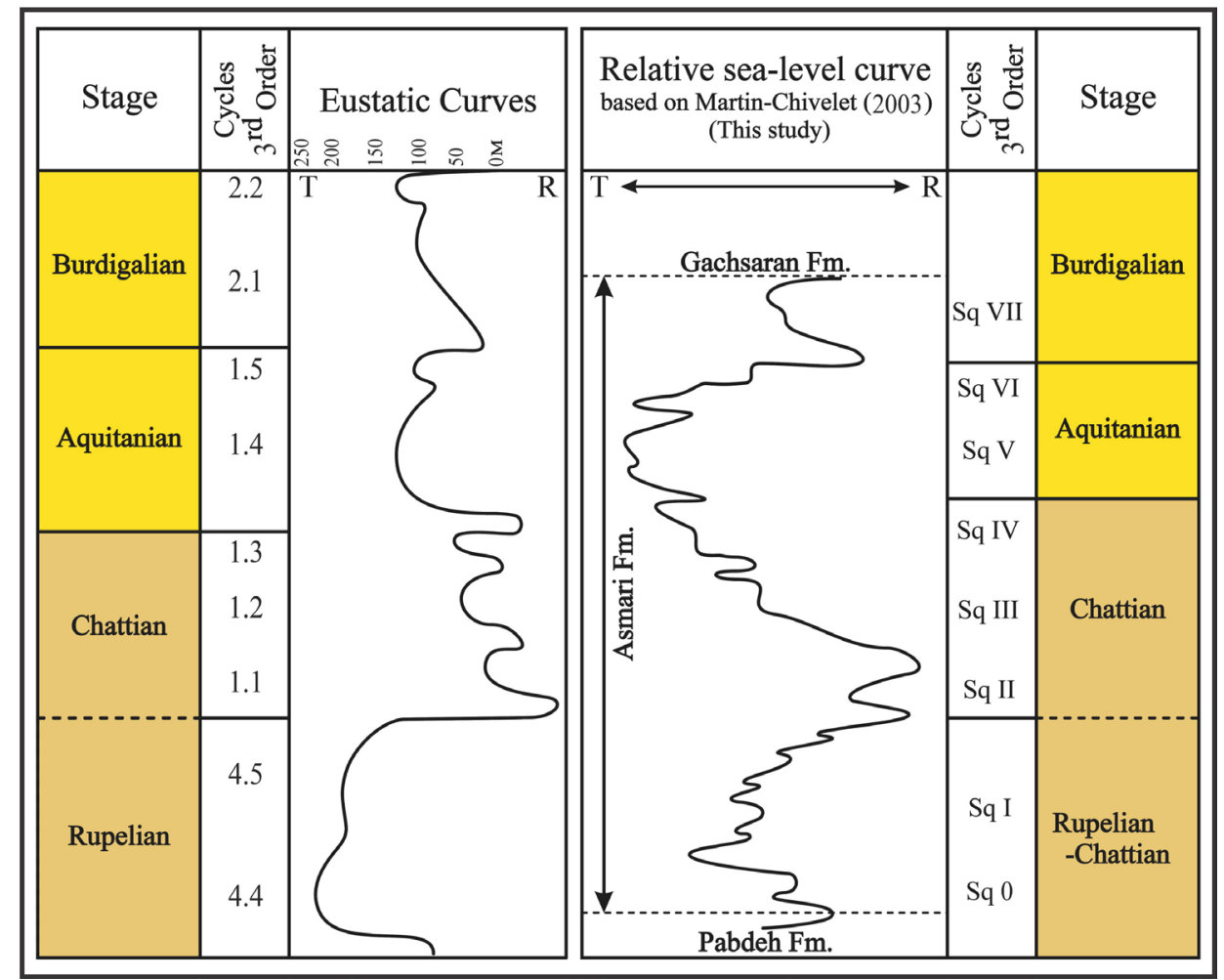

Figure 9. Vertical microfacies distribution, relative sea-level changes and sequence stratigraphic characteristics of the Asmari formation at Tang-e Khaiez (Khaviz Anticline). 
diments as TST. The TST is marked by a retrograding parasequence set which includes 3 parasequences and characterized by shoal and semi restricted microfacies that are overlain by open marine microfacies (Figure 8). These microfacies are: Mf7 (shoal microfacies; FA3), Mf5 (semi restricted marine microfacies; FA2), Mf2 and Mf1 (open marine microfacies; FA1); the latter representing the Mfs.

The HST of DS2 is characterized by a progradation from open marine microfacies (FA1; Mf1, Mf2 and Mf4) to semi restricted marine microfacies (FA2, Mf6). It consists of a prograding parasequence set, including 2 parasequences. The contact between DS1 and DS2 is of the $\mathrm{SB}_{\mathrm{II}}$ type (Figure 8). This sequence boundary (SB II) is comparable with sequence surface Ch20 proposed by Ehrenberg et al. [3] (Figure 10).

\subsubsection{Depositional Sequence 3}

Depositional sequence 3 is Chattian in age and is comparable with $3^{\text {rd }}$ order cycle no 1.2 proposed by Hag et al. [27] (Figure 9). Therefore, it formed during commence of Chattian transgression. Its lower boundary is characterized by a type 2 sequence boundary (Figure 8). The boundary (Sb III) is comparable with sequence surface Ch30 and with surface III reported by Ehrenberg et al. [3] and by Van Buchem et al. [4], respectively (Figure 10). A parasequence consists of Mf2 (open marine; FA1), and Mf5 (semi restricted marine; FA2) form TST of

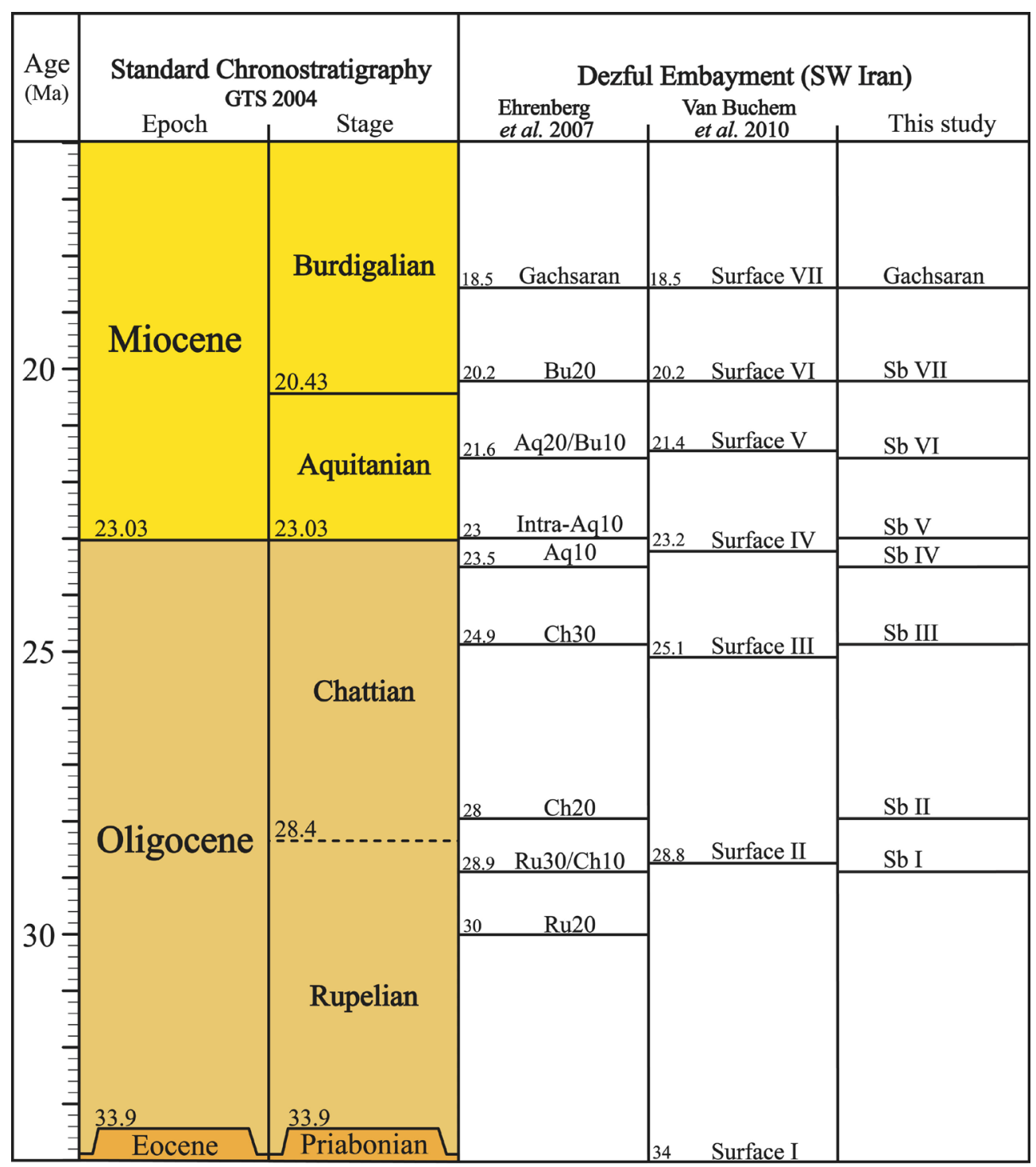

Figure 10. correlation between depositional sequences of Asmari formation in Khaviz area (this study) and Dezful Embayment (proposed by Ehrenberg et al. 2007, and Van Buchem et al. [4]. 
DS3, the earlier microfacies representing the Mfs. This portion of the sequence is $18.8 \mathrm{~m}$ thick.

The HST of the sequence is characterized by a prograding parasequence set composes of two parasequences (Figure 8). This part of DS3 is 17.4 thick and consists of open marine (Mf2; FA1), semi restricted marine (Mf5 and Mf6; FA2) and shoal microfacies (Mf7; FA3).

\subsubsection{Depositional Sequence 4}

This depositional sequence is Chattian in age and is $28.45 \mathrm{~m}$ thick. The TST of DS4 comprises of a retrograding parasequence set that consists of two parasequences (Figure 8). The thickness of TST is $7.5 \mathrm{~m}$ and composes of semi restricted (Mf5 and Mf6; FA2) and open marine microfacies. The HST of DS4 is characterized by a progradation from open (Mf2; FA1) and restricted facies (Mf5 and Mf6; FA2) to shoal facies (Mf7; FA3). Mf2 shows the mfs of this sequence (Figure 8).

The contact between DS3 and DS4 (SbIV) is of the SB $_{I I}$ type (Figure 8) and is comparable to sequence surface Aq10 proposed by Ehrenberg et al. [3] and surface IV reported by Van Buchem et al. [4] (Figure 10). Depositional sequence 5 is Chattian in age and is comparable with $3^{\text {rd }}$ order cycle no 1.3 proposed by Hag et al. [27] (Figure 9). Therefore, it formed during Chattian transgression.

\subsubsection{Depositional Sequence 5}

The transgressive systems tract (TST) of DS5 in this section is marked by microfacies of open marine, such as Mf2, Mf3 (FA1), and semi restricted like Mf5 (FA2, Figure 8). This portion of the sequence is $7.4 \mathrm{~m}$ thick and consists of a parasequence.

The highstand system tract (HST) of the sequence is marked by deposition of shoal packstone-grainstone (Mf8; FA3) on top of distal open marine microfacies (Mf1, Mf2 and Mf4; FA1; Figure 8). The Mf1, the deepest microfacies of open marine facies, points to Mfs of DS6. The HST is $30.2 \mathrm{~m}$ thick and consists of a prograding parasequence set which includes of 3 parasequences. The lower boundary of DS5 is characterized by a type 2 sequence boundary (Sb V) (Figure 8) that is comparable with sequence surface intra-Aq10 of sequence surfaces proposed by Ehrenberg et al. [3] (Figure 10). Depositional sequence 5 is Aquitanian in age and is comparable with $3^{\text {rd }}$ order cycle no. 1.4 proposed by Hag et al. [27] (Figure 9). Therefore, it was formed during Aquitanian transgression.

\subsubsection{Depositional Sequence 6}

The TST of DS6 shows a retrogradation from semi restricted facies (Mf5; FA2) and high-energy shoal facies (Mf7 and Mf8; FA3) to open marine microfacies (Mf1; FA1) the latter representing the Mfs (Figure 8). This system tract is $14.2 \mathrm{~m}$ and is made of a retrograding parasequence set includes two parasequences. The HST with $9.45 \mathrm{~m}$ thickness is made of a prograding parasequence set including two parasequences. Microfacies of these system tracts are: Mf2, Mf4 (open marine, FA1), Mf5 (semi restricted, FA2), Mf9 (shoal, FA3) and Mf11 (lagoon, FA4). Depositional sequence 6 is formed during the late Aquitanian regression so is comparable with $3^{\text {rd }}$ order cycle no 1.5 proposed by Hag et al. [27] (Figure 9). Contact between DS5 and DS6 is type 2 sequence boundary (Sb VI) and is equal with sequence surface Aq20/Bu10 and Surface V reported by Ehrenberg et al. [3] and by Van Buchem et al. [4], respectively (Figure 10).

\subsubsection{Depositional Sequence 7}

This depositional sequence is late Burdigalian in age and is $31.5 \mathrm{~m}$ thick. Transgressive system tract of this sequence is $25.7 \mathrm{~m}$ and abnormally consists of a prograding parasequence set including two parasequences. Increasing more carbonate production, compare to accommodation space, probably, is the reason of this trend [28]. Lagoon microfacies including Mf10 and Mf 11 (FA4) make this system tract. Mf10 represents its maximum flooding surface, too. The HST is introduced by fenestral mudstone (Mf12, peritidal; FA5) that lies on mfs (Figure 8). The lower boundary of DS7 in this area is characterized by a type 2 sequence boundary, whereas its upper boundary is defined by a type 1 sequence boundary (Figure 8). The lower boundary (Sb VII) is the same as sequence surface BU20 of Ehrenberg et al. [3] and surface VI of Van Buchem et al. [4] (Figure 10). DS7 is equivalent of the sequence no 2.1 of Hag et al. [27] (Figure 9).

\subsection{Interpretation of Sequences and Relative Sea Level Changes}

Whether the eight Oligocene- Early Miocene third-order cycles DS0 through DS 7 documented here are due to 
eustatic or tectonic control is therefore difficult to answer. Even though tectonic events may influence stratigraphic cyclicity at virtually any time scale [16], high frequency relative sea-level changes are also caused by differences in carbonate production rates or by variable wave- and current-controlled sediment accumulation rates at changing water depths. Because we do not observe widely changing thicknesses of sedimentary units or abrupt facies changes (except in DS6 and specially in DS7) in the study area which would point to local or regional tectonic instability, we rather suspect a global change in the Oligocene-Early Miocene rate of sea-level rise to have been the primary control on facies, depositional environments and stratigraphic architecture [4]. Such inference is also supported by the plausible match of the Asmari Formation sea level curve in this area, obtained with Martin-Chivelet's [17] method, with the global sea level curves of Haq et al. [27] (Figure 9).

\section{Conclusion}

The Asmari Formation in study area is composed of fine- to medium-grained, thin- to thick-bedded limestones including mudstone, wackestone, packstone, grainstones, rudstones and boundstones. These were formed in low- to high-energy homoclinal ramp environments in tidal-flat, lagoonal, shoal, semi restricted and open-marine settings along the foreland basin during the collision of Arabian plate and Iranian micro continent. Facies analysis based on dominant carbonate grain-size and the type and proportion of skeletal (molluscs, echinoderms, foraminifera, corals, and corallinacean) and non-skeletal grains (Ooids and peloids) in the Khaviz anticline allowed differentiating 5 facies associations (including 12 microfacies) ranging from tidal-flat to open-marine environments (inner ramp). Their lateral and vertical distribution pattern suggests a homoclinal ramp preserving eight third-order depositional sequences (DS0-DS7) between an HST of Rupelian-Chattian and a marked firstorder erosional sequence boundary of Lower Burdigalian in age. TST within each DS (except DS7) typically shows semi restricted and shoal facies overlain by open marine facies; the latter usually includes the mfs. During HST stages, open and semi restricted marine facies were gradationally overlain by shallow marine barrier and lagoonal facies in shallowing-upward trends, occasionally reaching into tidal-flat facies. Global eustatic changes were likely acted as primary drivers of the observed relative sea-level changes.

\section{Acknowledgements}

We would like to thank the logistical and financial support given to this study by the Islamic Azad University, Isfahan (Khorasgan) branch.

\section{References}

[1] Alavi, M. (2004) Regional Stratigraphy of the Zagros Fold-Thrust Belt of Iran and Its Proforeland Evolution. American Journal of Science, 304, 1-20. http://dx.doi.org/10.2475/ajs.304.1.1

[2] Ahmadhadi, F., Lacombe, O. and Marc Daniel, J. (2007) Early Reactivation of Basement Faults in Central Zagros (SW Iran), Evidence from Pre-Folding Fracture Populations in the Asmari Formation and Lower Tertiary Paleogeography. In: Lacombe, O., Lave, J., Roure, F. and Verges, J., Eds., Thrust Belts and Foreland Basins, Springer, Berlin, 205-228. http://dx.doi.org/10.1007/978-3-540-69426-7 11

[3] Ehrenberg, S.N., Pickard, N.A.H., Laursen, G.V., Monibi, S., Mossadegh, Z.K., Svana, T.A., Aqrawi, A.A.M., McArthur, J.M. and Thirlwall, M.F. (2007) Strontium Isotope Stratigraphy of the Asmari Formation (Oligocene-Lower Miocene), SW Iran. Journal of Petroleum Geology, 30, 107-128. http://dx.doi.org/10.1111/j.1747-5457.2007.00107.X

[4] Van Buchem, F.S.P., Allan, T.L., Laursen, G.V., Lotfpour, M., Moallemi, A., Monibi, S., Motiei, H., Pickard, N.A.H., Tahmasbi, A.R., Vedrenne, V. and Vincent, B. (2010) Regional Stratigraphic Architecture and Reservoir Types of the Oligo-Miocene Deposits in the Dezful Embayment (Asmari and Pabdeh Formations) SW Iran. Geology Society of London, Special Publication, 329, 219-263. http://dx.doi.org/10.1144/SP329.10

[5] Vaziri-Moghaddam, H., Seyrafian, A., Taheri, A. and Motiei, H. (2010) Oligocene-Miocene Ramp System (Asmari Formation) in the NW of the Zagros Basin, Iran: Microfacies, Paleoenvironment and Depositional Sequence. Revista Mexicana de Ciencias Geológicas, 27, 56-71.

[6] Sepehr, M. and Cosgrove, J.W. (2004) Structural Framework of the Zagros Fold-Thrust Belt, Iran. Marine Petroleum Geology, 21, 829-843. http://dx.doi.org/10.1016/j.marpetgeo.2003.07.006

[7] Sadeghi, R., Vaziri-Moghaddam, H. and Taheri, A. (2010) Microfacies and Sedimentary Environment of the Oligocene Sequence (Asmari Formation) in Fars Sub-Basin, Zagros Mountains, Southwest Iran. Facies, 57, 431-446. http://dx.doi.org/10.1007/s10347-010-0245-X 
[8] Sadeghi, R., Vaziri-Moghaddam, H. and Taheri, A. (2009) Biostratigraphy and Paleoecology of the Oligo-Miocene Succession in Fars and Khuzestan Areas (Zagros Basin, SW Iran). Historical Biology: An International Journal of Paleobiology, 21, 17-31. http://dx.doi.org/10.1080/08912960903033319

[9] Sooltanian, N., Seyrafian, A. and Vaziri-Moghaddam, H. (2011) Biostratigraphy and Paleo-Ecological Implications in Microfacies of the Asmari Formation (Oligocene), Naura Anticline (Interior Fars of the Zagros Basin), Iran. Carbonates Evaporites, 26, 167-180. http://dx.doi.org/10.1007/s13146-011-0053-6

[10] Amirshahkarami, M. (2013) Microfacies Correlation Analysis of the Oligocene-Miocene Asmari Formation, in the Central Part of the Rag-e-Safid Anticlinal Oil Field, Zagros Basin, South-West Iran. Turkish Journal of Earth Sciences, 22, 204-219.

[11] Seyrafian, A., Vaziri-Moghaddam, H., Arzani, N. and Taheri, A. (2011) Facies Analysis of the Asmari Formation in Central and North-Central Zagros Basin, Southwest Iran: Biostratigraphy, Paleoecology and Diagenesis. Revista Mexicana de Ciencias Geológicas, 28, 439-458.

[12] Stow, D.A.V. (2005) Sedimentary Rocks in the Field: The Color Guide. Manson Publishing, London. http://dx.doi.org/10.1201/b15204

[13] Wright, V.P. (1992) A Revised Classification of Limestone. Journal of Sedimentary Geology, 76, 177-185. http://dx.doi.org/10.1016/0037-0738(92)90082-3

[14] Flügel, E. (2010) Microfacies Analysis of Limestones, Analysis Interpretation and Application. Springer-Verlag, Berlin.

[15] Selly, R.C. (2001) Applied Sedimentology. 2nd Edition, Elsevier, Amsterdam.

[16] Catuneanu, O., Galloway, W.E., Kendall, C.G.S.C., Miall, A.D., Posamentier, H.W., Strasser, A. and Tucker, M.E. (2011) Sequence Stratigraphy: Methodology and Nomenclature. News of Stratigraphy, 44, 173-245. http://dx.doi.org/10.1127/0078-0421/2011/0011

[17] Martine-Chivelet, J. (2003) Quantitative Analysis of Accommodation Patterns in Carbonate Platforms: An Example from the Mid-Cretaceous of SE Spain. Palaeogeography, Palaeoclimatology, Palaeoecology, 200, 83-105. http://dx.doi.org/10.1016/S0031-0182(03)00446-2

[18] Barattolo, F., Bassi, D. and Romero, R. (2007) Upper Eocene Larger Foraminiferal-Coralline Algal Facies from the Klokova Mountain (South Continental Greece). Facies, 53, 361-375. http://dx.doi.org/10.1007/s10347-007-0108-2

[19] Bassi, D., Hottinger, L. and Nebelsick, H. (2007) Larger Foraminifera from the Upper Oligocene of the Venetian Area, Northeast Italy. Palaeontology, 50, 845-868. http://dx.doi.org/10.1111/j.1475-4983.2007.00677.x

[20] Mutti, M. and Hallock, P. (2003) Carbonate Systems along Nutrient and Temperature Gradients: Some Sedimentological and Geochemical Constraints. International Journal of Earth Sciences, 92, 465-475. http://dx.doi.org/10.1007/s00531-003-0350-y

[21] Nebelsick, J.H., Rasser, M. and Bassi, D. (2005) Facies Dynamic in Eocene to Oligocene Circumalpine Carbonates. Facies, 51, 197-216. http://dx.doi.org/10.1007/s10347-005-0069-2

[22] Brandano, M., Frezza, V., Tomassetti, L. and Cuffaro, M. (2009) Heterozoan Carbonates in Oligotrophic Tropical Waters: The Attard Member of the Lower Coralline Limestone Formation (Upper Oligocene, Malta). Palaeogeography, Palaeoclimatology, Palaeoecology, 274, 54-63. http://dx.doi.org/10.1016/j.palaeo.2008.12.018

[23] Brandano, M. and Corda, L. (2002) Nutrients, Sea Level and Tectonics: Constrains for the Facies Architecture of a Miocene Carbonate Ramp in Central Italy. Terra Nova, 14, 257-262. http://dx.doi.org/10.1046/j.1365-3121.2000.00419.x

[24] Cosovic, V., Drobne, K. and Moro, A. (2004) Paleoenvironmental Model from Eocene Foraminiferal Limestones of the Adriatic Carbonate Platform (Istrian Peninsula). Facies, 50, 61-75. http://dx.doi.org/10.1007/s10347-004-0006-9

[25] Pomar, L. (2001) Ecological Control of Sedimentary Accommodation: Evolution from a Carbonate Ramp to Rimmed Shelf, Upper Miocene, Balearic Islands. Palaeogeography, Palaeoclimatology, Palaeoecology, 175, 249-272. http://dx.doi.org/10.1016/S0031-0182(01)00375-3

[26] Shinn, E. (1983) Tidal Flats. In: Scholle, P.A., Bebout, D.G. and Moore, C.H., Eds., Carbonate Depositional Environments, AAPG Memoir 33, American Association of Petroleum Geologists, Tulsa, 171-210.

[27] Haq, B.U., Hardenbol, J. and Vail, P.R. (1987) Chronology of Fluctuating Sea Levels since the Triassic. Science, 235, 1156-1167. http://dx.doi.org/10.1126/science.235.4793.1156

[28] Mill, A.D. (1999) Principles of Sedimentary Analysis. Springer-Verlag, New York. 